\title{
Orientation of Small Hobby High Tunnels and Potential Effects on Cut Sunflowers and Fresh Herbs
}

\author{
Karen L. Panter ${ }^{1,4}$, Timmothy M. Gergeni ${ }^{2,3}$, \\ Casey P. Seals ${ }^{2,3}$, and Andrea R. Garfinkel ${ }^{2,3}$
}

AdDitional INDEX wORDs. Allium tuberosum, cut flowers, Helianthus annuus, hoop houses, Origanum majorana, Origanum vulgare

SUMMARY. High tunnels are gaining popularity for their use in horticultural crop production. However, little is known about the effect of high tunnel orientation on plant growth and development. In this set of studies, we show tunnel orientation does not necessarily affect the production of cut sunflower (Helianthus annuus) and culinary herbs oregano (Origanum vulgare), marjoram (Origanum majorana), and garlic chive (Allium tuberosum). Two high tunnels, one with the long axis oriented north-south (NS) and the other east-west (EW), were used to test the effects of high tunnel orientation on several crops over a 5-year period: cut sunflower (2012 and 2016); marjoram, oregano, and garlic chive (2013 and 2014); and garlic chive (2015). The tunnels are $12 \times 16 \mathrm{ft}$, smaller than those used in commercial production. The size would be appropriate for hobby and seasonal production of horticultural crops for local markets. Cut sunflower stems were similar lengths both years in both high tunnels. Sunflower times to harvest were different between cultivars but not between high tunnels. Oregano fresh weight yields were highest in the NS tunnel in 2013 but similar between tunnels in 2014. Marjoram fresh weights were highest in 2013 in the EW tunnel but highest in 2014 in the NS tunnel. Garlic chive fresh weights were similar between tunnels all 3 years. We show that differences are more a function of innate cultivar characteristics than which way small high tunnels are oriented.

$\mathrm{H}$ igh tunnels are important alternatives to greenhouse or field production of highvalue crops such as cut flowers and herbs (Carey et al., 2009; Wells and Loy, 1993; Wien, 2009b). Many cut flowers and herbs produced in the United States are grown in open field settings where year-round production is possible (Bonarriva, 2003); however, the interest in locally produced horticultural goods has driven the regional production of these crops

Received for publication 9 Jan. 2019. Accepted for publication 23 Apr. 2019.

Published online 6 June 2019

The authors appreciate funding support from the Wyoming Department of Agriculture Specialty Crops Grant Program and from the University of Wyoming Agricultural Experiment Station.

${ }^{1}$ Plant Sciences - Department 3354, University of Wyoming, 1000 East University Avenue, Laramie, WY 82071

${ }^{2}$ Department of Plant Sciences, University of Wyoming

${ }^{3}$ Former graduate student.

${ }^{4}$ Corresponding author. E-mail: kpanter@uwyo.edu.

This is an open access article distributed under the CC BY-NC-ND license (https://creativecommons.org/ licenses/by-nc-nd/4.0/).

https://doi.org/10.21273/HORTTECH04273-19 into greenhouses, high tunnels, and other season-extending environments (Cavins et al., 2000; Ortiz et al., 2012; Wien, 2009a). Not only do high tunnels allow for a local extended growing season, but they also play an important role in protecting cut flower crops from extreme environmental conditions, including freezing temperatures, rain, wind, hail, and in some cases, disease (Lamont, 2009; Wien, 2009a). The increased interest in domestic production of cut flowers and herbs in high tunnels and the advantages of high tunnel production create the need for region- and crop-specific research to maximize local production potential (Ferguson et al., 2012; Lamont, 2009; Ortiz et al., 2012).

Numerous factors may affect growth of crops in high tunnels, including orientation of the structure (Sethi, 2009). General studies on high tunnel orientation indicate that growers in the northern hemisphere should orient high tunnels with the long sides running NS to maximize solar radiation (Sethi, 2009). Despite this recommendation, there is evidence to show that the benefits of high tunnel orientation and growing location within a particular orientation may be crop-specific. Taber et al. (2009) showed that tunnel orientation and planting location within a high tunnel negatively affected bean (Phaseolus vulgaris) yield, with decreased productivity of bean plants grown in north (in an EW-oriented tunnel) and west (in a NS-oriented tunnel) growing locations.

The sunflower will flower from 75 to $150 \mathrm{~d}$ after sowing (FernándezMartinez et al., 2009), with temperature and photoperiod significantly affecting time from sowing to maturity (Fernández-Martinez et al., 2009; Schuster, 1985). Cool temperatures delay flowering, whereas warm temperatures accelerate maturation (FernándezMartinez et al., 2009).

Due to their hardiness, garlic chive is described as being low maintenance (Folia, 2015). Chive plants do best in full sun or part shade, and well-drained but moist soil (Gardener's Network, 2016). Recommended growing temperature is $\mathbf{5 8}$ ${ }^{\circ} \mathrm{F}$ (Nau, 1999).

Oregano and marjoram require similar growing temperatures of $\approx \mathbf{5 5}$ ${ }^{\circ} \mathrm{F}$. Both are frost-sensitive and are typically grown as annuals in colder climates, unless under controlled environments (Nau, 1999). 
Although a number of studies have assessed the potential for producing cut sunflowers and herbs in high tunnels (Cavins et al., 2000; Lamont, 2009; Lopez and Ortiz, 2012; Ortiz et al., 2012; Wien, 2006), none report on the effect of high tunnel orientation or growing location on plant growth. Thus, we set up a series of trials with the objective of determining differences in growth of cut sunflowers and fresh herbs between high tunnel orientations. The tunnels are small hobby size; therefore, these studies are appropriate for part-time growers interested in seasonal production of horticultural crops for local markets. This work represents a combination of three different graduate students' effort over 4 years; some differences in methodology occurred as a result.

\section{Materials and methods Site background}

Experiments were conducted at the University of Wyoming Laramie Research and Extension Center greenhouse complex. The facility is located in Laramie, WY (lat. $41^{\circ} 19^{\prime} 12^{\prime \prime} \mathrm{N}$, long. $105^{\circ} 33^{\prime} 31^{\prime \prime} \mathrm{W}$, elevation of $7200 \mathrm{ft}$ ) in U.S. Department of Agriculture cold hardiness zone $4 \mathrm{~b}$ (Fig. 1C).

\section{High tunnels}

The high tunnels used in this study were two $12 \times 16-\mathrm{ft}$ archroof-style tunnels (Solar Star Greenhouses; Growers Supply, Dyersville, IA) covered in a double layer of 6-mil uninflated polyethylene plastic with double-walled polycarbonate end walls. Both tunnels had manual roll-up sides, up to $\approx 3 \mathrm{ft}$, to provide ventilation. Sides were rolled up when temperatures exceeded $40{ }^{\circ} \mathrm{F}$ and down when temperatures dipped below $40^{\circ} \mathrm{F}$. The two tunnels were oriented in different directions, one with the long axis running NS and the other EW (Fig. 2). In Apr. 2012, 2013, and 2015 , before planting, soil in the tunnels was amended with 2 inches of peatmoss and compost, spaded into a depth of 6 inches. Soil in the tunnels is described as sandy loam.

\section{Sunflower}

Two cultivars of fresh-cut sunflower were grown in 2012 and 2016. Cultivar selections were based on flower color (brown and gold, the University of Wyoming's colors) and single-stem characteristics. Singlestem sunflowers do not branch. One seed equals one plant that produces one solitary flowering stem (Harris Seeds, Rochester, NY). The cultivars were Dafna and ProCut Bicolor (Harris Seeds) (Fig. $1 \mathrm{~A}$ and $\mathrm{B}$ ).

Sunflower 2012. The two sunflower cultivars were arranged in a randomized complete block design with four replications of four plants each per cultivar arranged in a two-by-two square with plants on 6-inch centers. Blocks were arranged on either side of the central aisle in each high tunnel, four blocks on either side, eight blocks total per tunnel. An edge row was planted around the perimeter of all sunflower plots to mitigate edge effects.

Sunflower 2016. The same two cultivars were arranged in a completely random design with 20 singleplant replicates per cultivar on 6-inch centers. Twenty plants were randomized on each side of the central aisle in each high tunnel, 40 plants total per tunnel. An edge row was planted around the perimeter of all plots to mitigate edge effects. Different students pursued these studies in 2012 and 2016; thus the differences in methodology between the 2 years.

Propagation. Seeds were sown on 2 May 2012 and 26 May 2016 in 128 -cell plug trays in a professional germination medium (Fafard Super Fine Germinating Mix; Conrad Fafard, Agawam, MA) and maintained in a greenhouse $70 / 65^{\circ} \mathrm{F}$ day/night on a mist bench. Misting was controlled with an automated clock system (Schaefer Solar 3B; Pinnacle Climate Technologies, Sauk Rapids, MN). The mist system was set to trigger on for $20 \mathrm{~s}$ for every 20 solar units collected, where one solar unit is equal to $0.02 \mathrm{~mol} \cdot \mathrm{m}^{-2}$ light. Seeds from different cultivars, Sunrich Gold (2012) and Sunbright Supreme (2016) (Harris Seeds), were sown on the same schedule and were used as edge rows.

After 15 d (17 May 2012 and 10 June 2016), seedlings were transplanted on 6-inch centers directly into the ground in the high tunnels and immediately irrigated. Thirteen $\mathrm{d}$ following transplant, each plant was top-dressed with $2.5 \mathrm{~g}$ (1076.4 $\mathrm{kg} \cdot \mathrm{ha}^{-1}$ ) $15 \mathrm{~N}-4.4 \mathrm{P}-9.9 \mathrm{~K}$ controlledrelease fertilizer (Osmocote Plus 159-12; ICL Specialty Fertilizers, Dublin, $\mathrm{OH})$. Throughout production, sunflowers were watered by hand daily. Plants were grown under natural light and daylength conditions experienced in the hobby high tunnels.

\section{Herbs}

Three species of fresh culinary herbs were chosen for study in 2013 and 2014: oregano, marjoram, and garlic chive (Fig. 1C). The latter was used in 2015. Each of the species in all 3 years was grown as $16(2013$ and 2014) and 24 (2015) singleplant replicates. Each group of one species was grown together in one plot; plots were randomly placed one on each side of the central aisle in each tunnel (Fig. 1C). Plots were completely surrounded by edge rows of a combination of lavender ( $L a v-$ andula angustifolia) and rosemary
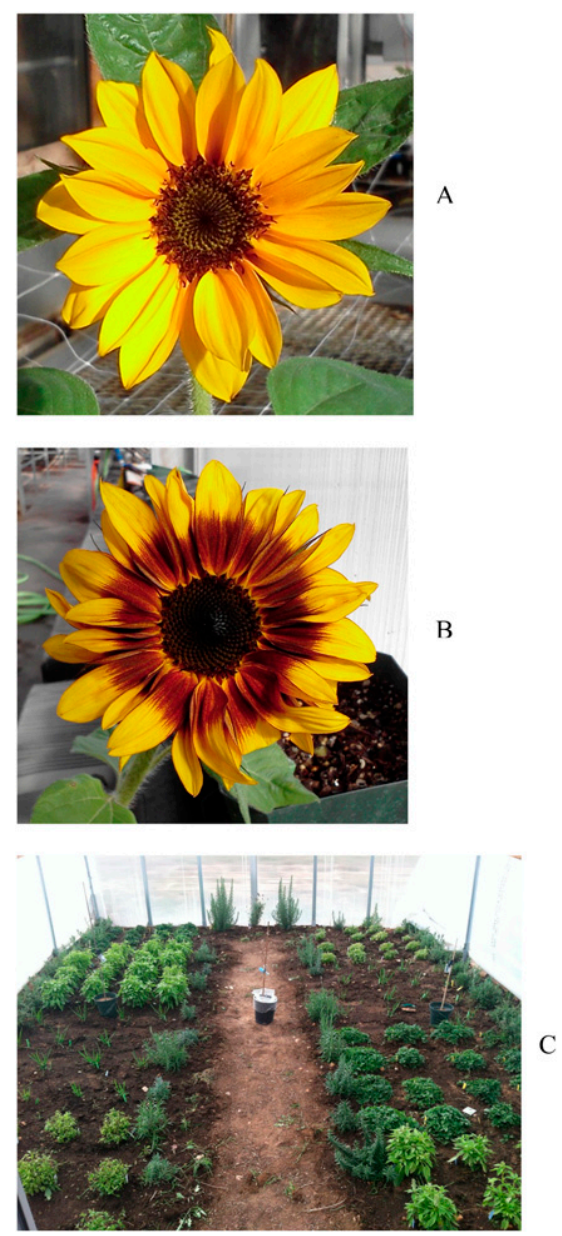

Fig. 1. Photos of plants used in high tunnel orientation studies. Fresh-cut sunflower cultivars grown were Dafna (A) and ProCut Bicolor (B) in 2012 and 2016. Fresh herbs grown are shown in (C), with the photo taken of crops in the high tunnel oriented north-south in 2013. 
(Rosmarinus officinalis) plants. Again, differences in methodology reflect different students handling the work.

Propagation. All plants were grown from seeds (Harris Seeds). Sowings occurred 4 Apr. 2013, 15 Apr. 2014, and 8 Mar. 2015. Seeds were sown in 128-cell plug trays in a professional germination medium (Fafard Super Fine Germinating Mix). Plug trays were placed on a mist bench using a solar mist controller (Schaefer Solar 3B) set to come on for $20 \mathrm{~s}$ every 20 solar counts. Following germination, seedlings were transplanted directly into the ground in the high tunnels on 12 -inch centers: 30 May 2013, 24 May 2014, and 22 May 2015. Ten days following transplant, each plant was top-dressed with $2.5 \mathrm{~g}\left(538.2 \mathrm{~kg} \cdot \mathrm{ha}^{-1}\right) \quad 15 \mathrm{~N}-$ $4.4 \mathrm{P}-9.9 \mathrm{~K}$ controlled-release fertilizer (Osmocote Plus 15-9-12). Throughout production, herbs were watered by hand once daily. Plants were grown under natural light and daylength conditions.

\section{Light and temperature measurements}

Environmental monitors (HOBO Pendant Temperature/Light Data Logger 64K, UA-002-64HOBO; Onset Computer Corp., Bourne, MA) were positioned 12 inches above the ground in the center of each block of plants to record air temperature and light levels, two per high tunnel, four sensors total in 2012 through 2015.

Soil temperatures were monitored using data loggers $(\mathrm{HOBO}$ Pendant Temperature Data Logger 64K, UA-001-64; Onset Computer Corp.). Each was buried 4 inches deep in the soil in the center of the long axis of each tunnel, $\approx 4$ inches from the outside wall. Thus, there were two data loggers per high tunnel, four total (Fig. 2). All data loggers were programmed to collect data every $4 \mathrm{~h}$ starting at midnight.

\section{Soil analyses}

Soil analyses in each tunnel were conducted in spring 2013,2014, and 2015 (Colorado Analytical Laboratories, Brighton, $\mathrm{CO}$ ). Results indicated minor differences in characteristics between the two tunnels. The soil texture was sandy loam. In 2013, $\mathrm{pH}$ and electrical conductivity (EC) were 7.9 and $1.3 \mathrm{dS} \cdot \mathrm{m}^{-1}$, respectively,
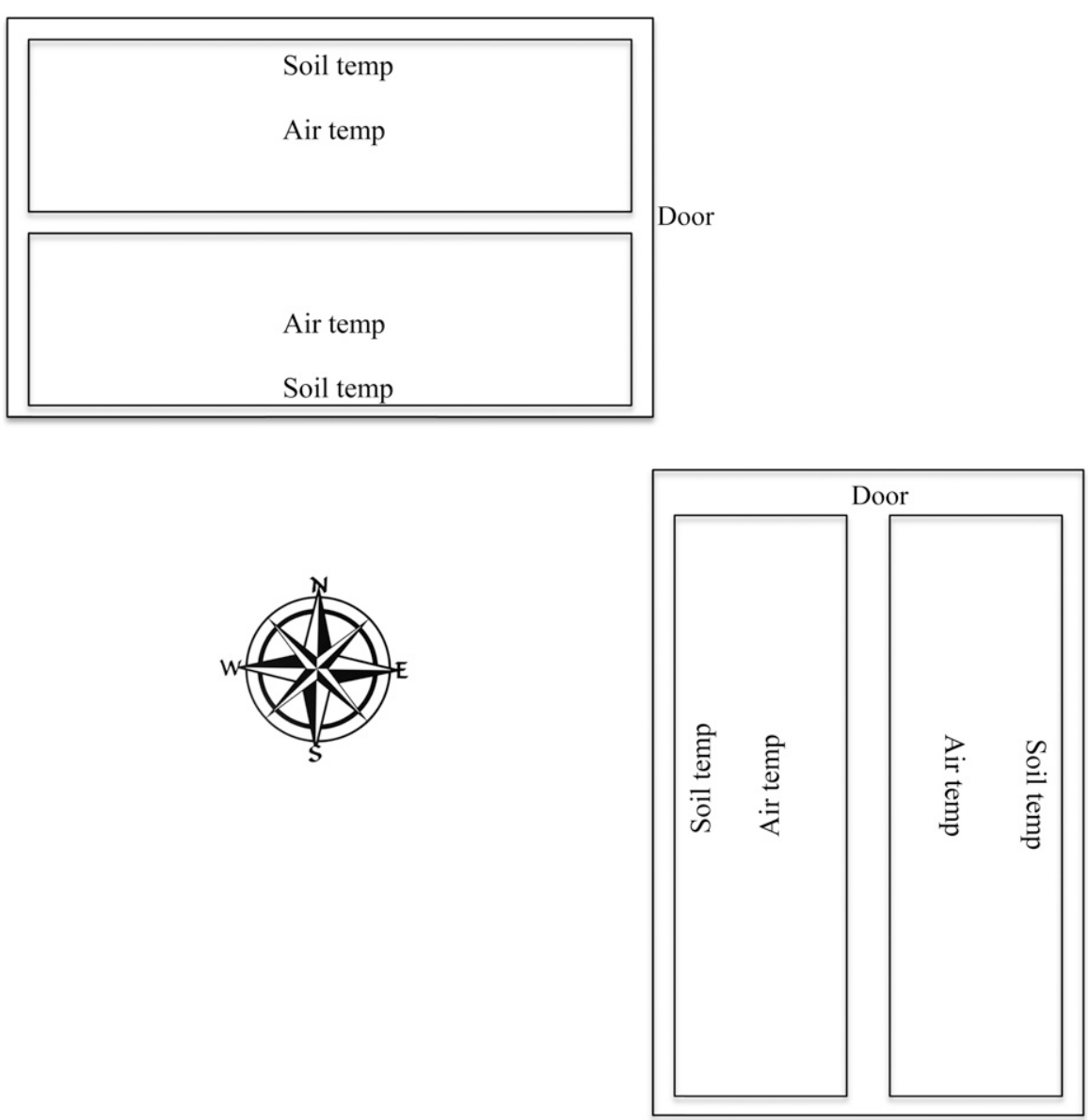

Fig. 2. Diagram of two high tunnels oriented perpendicular to one another. Each is $12 \times 16 \mathrm{ft}$. One is oriented with the long axis north-south and the other with the long axis east-west. The high tunnels are located at the University of Wyoming Laramie Research and Extension Center in Laramie, WY (lat. $41^{\circ} 19^{\prime} 12^{\prime \prime} \mathrm{N}$, long. $105^{\circ} 33^{\prime} 31^{\prime \prime} \mathrm{W}$, elevation $7200 \mathrm{ft}$ ). Plants were grown on either side of the central aisle in each high tunnel. Air temperatures were monitored in the center of the growing area of each tunnel at 12 inches, and soil temperatures were monitored 4 inches deep in the center of the long side of each high tunnel; $1 \mathrm{ft}=0.3048 \mathrm{~m}$, 1 inch $=2.54 \mathrm{~cm}$.

in the NS tunnel and 7.7 and 1.5 $\mathrm{dS} \cdot \mathrm{m}^{-1}$ in the EW tunnel. In 2014 the analysis results were $\mathrm{pH} 7.6$ and EC 2.6 in the NS tunnel and 7.4 and 3.6 in the EW tunnel. In $2015, \mathrm{pH}$ levels in the NS tunnel were 7.6 with $\mathrm{EC}$ at $1.2 ; \mathrm{EW}$ pH was 7.7 with EC at 1.3 .

Organic matter $(\mathrm{OM})$ levels were below $5 \%$ in both tunnels. In 2013 , the NS tunnel OM was $3.5 \%$, and the EW tunnel was $3.1 \%$. In 2014, the figures were $4.5 \%$ in the NS tunnel and $4.9 \%$ in the EW tunnel. In 2015 , levels were NS tunnel $3.5 \%$ and EW tunnel $2.9 \%$.

\section{Harvesting and data collection}

SuNFLOWER. Individual flowers were harvested when ray flowers were open (Dole and Wilkins, 1999), as per industry standard. Harvest occurred approximately every other day. Stems were cut at the soil level and stem lengths were immediately measured and recorded. The length of the stem was measured from the soil level where the cut was made to the base of the flower head receptacle. Data were also collected on time to harvest from sowing (days).

Herbs. In 2013 and 2014, oregano and marjoram were harvested periodically during the growing season, just before flower initiation, at their peak culinary flavor (Morgan, 2005), as per industry standard. These were harvested by hand leaving two to three nodes on each stem for regrowth. Garlic chive was harvested 
when the aboveground biomass was at least 6 inches tall, cut to 2 inches aboveground. Harvested materials were immediately weighed for fresh weight. All fresh weights were measured using a portable scale (PC 4400; Mettler-Toledo International, Greifensee, Switzerland). In 2015, garlic chive was harvested once at the end of the growing season for total fresh weight, 10 Sept., and weighed using a portable scale (model SLB50; Carolina Biological Supply Co., Burlington, NC).

\section{Statistical analysis}

Data were analyzed and statistical computations were facilitated using analysis of variance procedure in SAS (version 9.3 or 9.4; SAS Institute; Cary, NC). Means separations were conducted using Fisher's least significant difference at $\alpha=0.05$.

\section{Results \\ Sunflower: Time to harvest}

2012. Time to harvest did not differ between NS and EW high tunnel orientations (Table 1). The only differences observed in time to harvest were between cultivars. Time to harvest between the two high tunnel orientations, NS vs. EW, for 'ProCut Bicolor' averaged 77 and 79 d, respectively, which was significantly fewer than 'Dafna' at 95 and $94 \mathrm{~d}$, respectively (Table 1 ).

2016. Time to harvest again differed between the cultivars Dafna and ProCut Bicolor but there were no differences between the two high tunnel orientations. 'Dafna' averaged $80 \mathrm{~d}$ in both high tunnels, whereas 'ProCut Bicolor' averaged $71 \mathrm{~d}$ in the NS tunnel and $76 \mathrm{~d}$ in the EW tunnel (Table 1).

\section{Sunflower: Stem lengths}

2012. Neither 'Dafna' nor 'ProCut Bicolor' differed in stem length between cultivars or the two high tunnel orientations (Table 1 ).

2016. There were no differences in stem lengths between cultivars or high tunnels (Table 1 ).

\section{Herbs: Time to harvest}

2013, 2014, and 2015. No differences occurred in time to harvest from sowing between the two high tunnels with any crop in either 2013 or 2014 , because each crop was harvested the same days in both high tunnels (data not shown). In 2015, all garlic chives were harvested at once at the end of the growing season, so no differences in time to harvest occurred that year either (data not shown).

\section{Herbs: Fresh weights}

2013. There were no differences in fresh weight yields per plant between the two high tunnel orientations with garlic chive. An average of $13 \mathrm{~g}$ of garlic chive per plant was harvested from the NS tunnel and $16 \mathrm{~g}$ from the EW tunnel (Table 2). Marjoram and oregano per plant fresh weights differed between the two high tunnels (Table 2). Marjoram per plant fresh weight in the EW tunnel was $115 \mathrm{~g}$, significantly higher than in the NS tunnel, $85 \mathrm{~g}$ (Table 2). Oregano showed the opposite, with higher per plant fresh weight in the NS tunnel at $117 \mathrm{~g}$ than the EW tunnel, $89 \mathrm{~g}$ (Table 2).

Table 1. Results of analysis of variance and means separation in fresh-cut sunflower time to harvest from sowing and stem lengths when grown in two high tunnels in 2012 and 2016. One high tunnel was oriented with the long axis oriented north-south (NS), and the other was oriented east-west (EW).

\begin{tabular}{llccc}
\hline Yr & Cultivar & $\begin{array}{c}\text { High } \\
\text { tunnel }\end{array}$ & $\begin{array}{c}\text { Mean time to } \\
\text { harvest }(\mathbf{d})\end{array}$ & $\begin{array}{c}\text { Mean stem } \\
\text { length }(\mathbf{c m})^{\mathbf{z}}\end{array}$ \\
\hline 2012 & Dafna & NS & $95 \mathrm{a}^{\mathrm{y}}$ & $123 \mathrm{a}$ \\
& ProCut Bicolor & EW & $94 \mathrm{a}$ & $110 \mathrm{a}$ \\
& & NS & $77 \mathrm{~b}$ & $103 \mathrm{a}$ \\
2016 & Dafna & EW & $79 \mathrm{~b}$ & $109 \mathrm{a}$ \\
& \multirow{3}{*}{ ProCut Bicolor } & NS & $80 \mathrm{a}$ & $82 \mathrm{a}$ \\
& & EW & $80 \mathrm{a}$ & $84 \mathrm{a}$ \\
& & NS & $71 \mathrm{~b}$ & $81 \mathrm{a}$ \\
& & EW & $76 \mathrm{~b}$ & $72 \mathrm{a}$ \\
\hline
\end{tabular}

${ }^{\mathrm{z}} 1 \mathrm{~cm}=0.3937$ inch.

y'Different letters within a year, cultivar, and column indicate statistical differences using Fisher's least significant difference means separation at $\alpha=0.05$.

Table 2. Results of analysis of variance and means separation of fresh weight of culinary herbs garlic chive, marjoram, and oregano, grown in two high tunnels in 2013,2014 , and 2015. One high tunnel was oriented with the long axis oriented north-south (NS), and the other was oriented east-west (EW).

\begin{tabular}{lcccr}
\hline \multicolumn{5}{c}{ Mean fresh wt $(\mathrm{g} / \text { plant })^{\mathrm{z}}$} \\
\hline Yr & High tunnel & Garlic chive & Marjoram & Oregano \\
\hline 2013 & NS & $13 \mathrm{a}^{\mathrm{y}}$ & $85 \mathrm{~b}$ & $117 \mathrm{a}$ \\
& EW & $16 \mathrm{a}$ & $115 \mathrm{a}$ & $89 \mathrm{~b}$ \\
2014 & NS & $37 \mathrm{a}$ & $145 \mathrm{a}$ & $106 \mathrm{a}$ \\
& EW & $40 \mathrm{a}$ & $110 \mathrm{~b}$ & $106 \mathrm{a}$ \\
2015 & NS & $22 \mathrm{a}$ & Not grown & Not grown \\
& EW & $25 \mathrm{a}$ & Not grown & Not grown \\
\hline
\end{tabular}

${ }^{\mathrm{z}} \mathrm{lg}=0.0353 \mathrm{oz}$.

yDifferent letters within a year, herb, and column indicate statistical differences using Fisher's least significant difference means separation at $\alpha=0.05$. 
10 July of $106.8^{\circ} \mathrm{F}$ in the EW tunnel and $105.8^{\circ} \mathrm{F}$ in the NS tunnel. Average soil temperatures in the east and south planting locations were statistically higher than those in the west and north locations in 2012, 2013, and 2015 ; in 2014, east average soil temperature was higher than the other three edges (Table 3 ). Soil temperatures within the hobby high tunnels were consistently lower than air temperatures (Table 3 ).

Light levels differed between high tunnels depending on the time of day, as shown in data from 2012, a representative year (Fig. 3). Lower average light levels were recorded in the NS tunnel than the EW tunnel, particularly at 0800 and $1200 \mathrm{HR}$ (Fig. 3).

\section{Discussion}

\section{Sunflower: Time to harvest}

The similarities between high tunnel orientations with regard to time to harvest were expected because all were grown under the same photoperiod. Photoperiod has been shown to be the major factor in determining flower initiation and maturation of cut sunflowers (Blacquière et al., 2002; Gimelli et al., 2003; Hayata and Imaizumi, 2000; Pallez et al., 2002; Yañez et al., 2004, 2005). Variation in time to harvest between the two cultivars tested in this study are in accordance with research that suggests that cut sunflowers are sensitive to photoperiod and that this response is cultivar-specific (Wien, 2012a, 2012b). Wien (2012a, 2012b) showed that 'ProCut Bicolor' flowered faster under summer, long-day conditions, whereas 'Dafna' is slower to bloom during long-day conditions. Fourteen hours has been shown to be the critical daylength to elicit a longday sunflower response (Blacquière et al., 2002); daylength exceeded 14 $\mathrm{h}$ throughout both years of study.

\section{Sunflower: Stem lengths}

Because stem lengths were similar between the two high tunnels, lower light intensities in the NS high tunnel were apparently not different enough to cause stem lengths to differ. In our other studies conducted on sunflower responses to light (Garfinkel and Panter, 2014), we found light intensity contributed to differences in stem length of cut sunflowers when grown in a greenhouse. Soil temperature differences in our studies were statistically different but not

Table 3. Mean high tunnel air $(2013,2014,2015)$ and soil temperatures $(2012$, 2013,2014 , and 2015). Two high tunnels were used, one with the long axis oriented north-south and the other east-west. Crops grown were fresh-cut sunflowers or fresh culinary herbs. Locations within high tunnels were as follows: north and south sections in the east-west tunnel, and east and west sections in the north-south tunnel. Temperatures were recorded every $4 \mathrm{~h}$.

\begin{tabular}{lccc}
\hline Yr & $\begin{array}{c}\text { Location within } \\
\text { high tunnel }\end{array}$ & Air temp $\left({ }^{\circ} \mathbf{C}\right)^{\mathbf{z}}$ & Soil temp $\left({ }^{\circ} \mathbf{C}\right)$ \\
\hline 2012 & North & NA & $14.4 \mathrm{~b}^{\mathrm{x}}$ \\
& South & NA & $15.7 \mathrm{a}$ \\
East & NA & $15.7 \mathrm{a}$ \\
2013 & West & NA & $14.6 \mathrm{~b}$ \\
& North & $19.2 \mathrm{a}$ & $15.4 \mathrm{~b}$ \\
& South & $19.5 \mathrm{a}$ & $17.0 \mathrm{a}$ \\
& East & $20.7 \mathrm{a}$ & $16.8 \mathrm{a}$ \\
& West & $20.0 \mathrm{a}$ & $16.6 \mathrm{~b}$ \\
& North & $18.8 \mathrm{a}$ & $15.6 \mathrm{a}$ \\
& South & $18.6 \mathrm{a}$ & $15.8 \mathrm{a}$ \\
& East & $19.6 \mathrm{a}$ & $16.6 \mathrm{a}$ \\
& West & $18.7 \mathrm{a}$ & $15.6 \mathrm{a}$ \\
& North & $25.7 \mathrm{a}$ & $18.4 \mathrm{~b}$ \\
& South & $26.1 \mathrm{a}$ & $20.0 \mathrm{a}$ \\
& East & $26.4 \mathrm{a}$ & $20.3 \mathrm{a}$ \\
& West & $25.6 \mathrm{a}$ & $18.3 \mathrm{~b}$ \\
\hline
\end{tabular}

${ }^{\mathrm{z}}\left(1.8 \times{ }^{\circ} \mathrm{C}\right)+32={ }^{\circ} \mathrm{F}$

${ }^{y}$ Not applicable; air temperatures were not recorded in 2012.

${ }^{x}$ Different letters within a year, location, and column indicate statistical differences using Fisher's least significant difference means separation at $\alpha=0.05$.

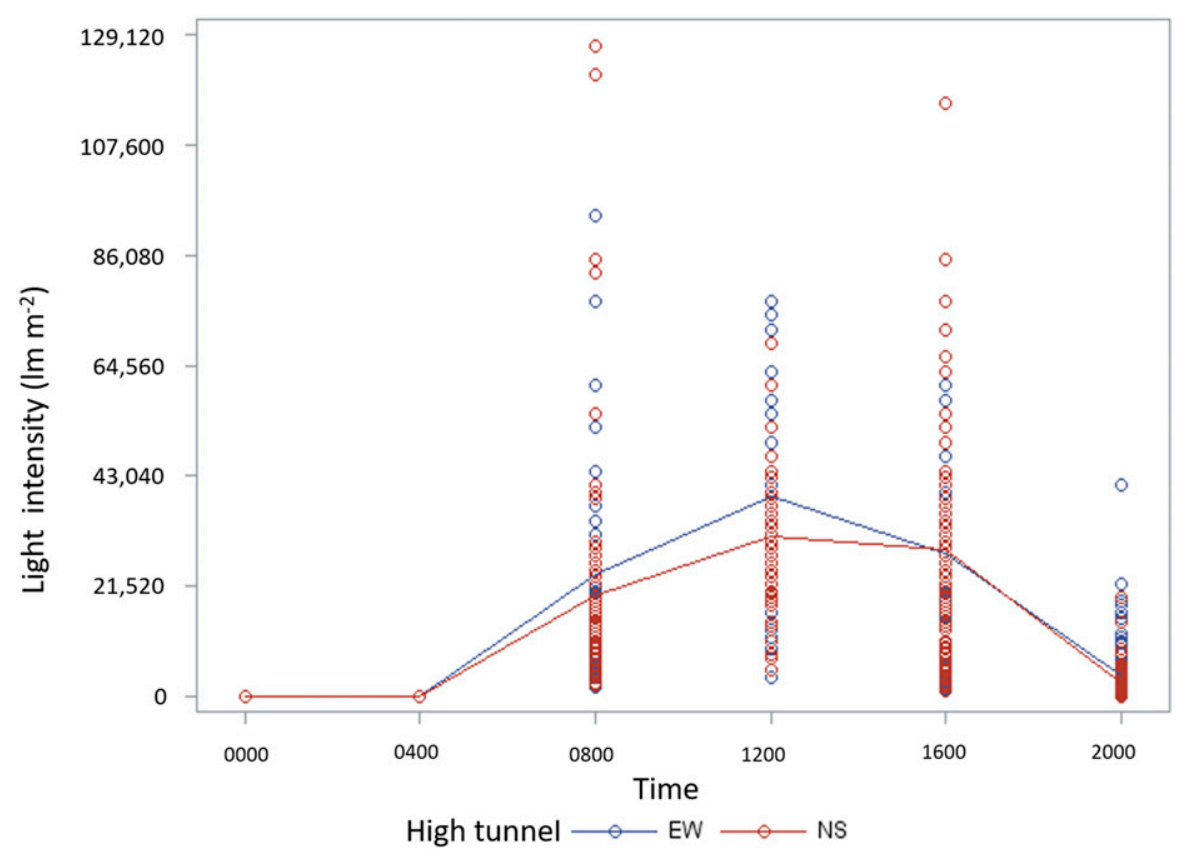

Fig. 3. Plot of light intensity by high tunnel orientation and time of day. Data are from two high tunnels oriented perpendicular to one another, one with the long axis north-south [NS (red)] and the other east-west [EW (blue)]. Data were recorded every $4 \mathrm{~h}$ starting at midnight 17 May 2012 through 7 Oct. 2012. Each is $12 \times 16 \mathrm{ft}$. The high tunnels are located at the University of Wyoming Laramie Research and Extension Center in Laramie, WY (lat. $41^{\circ} 19^{\prime} 12^{\prime \prime} \mathrm{N}$, long. $105^{\circ} 33^{\prime} 31^{\prime \prime} \mathrm{W}$, elevation $\left.7200 \mathrm{ft}\right) ; 1 \mathrm{ft}=0.3048 \mathrm{~m}, 1 \mathrm{~lx}=0.0929 \mathrm{fc}$.

biologically, because stem lengths were the same between the two tunnels. Optimum soil temperatures for sunflowers are $\approx 68{ }^{\circ} \mathrm{F}$ (McMichael and Burke, 1998). Our soil temperatures were lower than recommended, but this did not contribute to parameters measured. 


\section{Herbs}

2013, 2014, AND 2015. Differences in fresh weights among the three species did not show any particular patterns among the 3 years. Fresh weights of the three species varied by year and high tunnel with no easily discernable cause. Reasons for higher fresh weights in general in 2014 probably include the human component of simply being more experienced growers. It seems differences between the tunnels in soil temperatures, light levels, and soil properties had little effect overall. Soil temperatures were slightly lower in 2014, but fresh weights were slightly higher that year. Light levels between the two tunnels were slightly higher in the EW tunnel but herb fresh weights were not always higher in that tunnel in either year. Soil temperatures were lower on the north and west sides, but only in 2013, not 2014.

Parameters for optimum growth of oregano and sweet marjoram include temperatures of 65 to $70{ }^{\circ} \mathrm{F}$ days and 55 to $62^{\circ} \mathrm{F}$ nights (Nau, 2011). Temperatures in the two high tunnels were within these ranges in 2013 and 2014 , indicating temperatures were not a factor in fresh weight differences. Recommended $\mathrm{pH}$ levels for these two herbs are between 4.9 and 8.7, with optimum at $\approx 6.9$ (Savio and Robinson, 1998); ours were in this range, indicating soil properties did not lead to fresh weight differences.

Chive generally requires temperatures of 55 to $60^{\circ} \mathrm{F}$ days and 40 to $55^{\circ} \mathrm{F}$ nights (Nau, 2011). Our temperatures were warmer than recommended but were similar between the two tunnels, so were not factors in fresh weight differences. The recommendation for $\mathrm{pH}$ is between 5.8 and 7.0 (Andersen, n.d.), lower than ours. However, we saw no differences between tunnels in chive fresh weights.

\section{Environment}

Although these high tunnels are small and hobby-sized, this did not influence crop production parameters. Recommendations are for high tunnels to be oriented perpendicular to prevailing winds (Jett, 2004); however, because our two high tunnels were open with the sides rolled up during all five growing seasons, temperatures were consistent within the two. Air temperatures were higher in 2015 than the previous 2 years, but garlic chive fresh weights were intermediate in 2015 , between those from the two previous years. It seems air temperatures are not a contributing factor in herb yields or sunflower time to harvest or stem lengths; however, soil temperatures were consistently lower on the north side of the EW tunnel and the west side of the NS tunnel.

\section{Conclusions}

Our data suggest that in small tunnels with these dimensions in this location, orientation was not a primary production consideration. In this series of experiments, we found that stem lengths of two cultivars of sunflower were unaffected by high tunnel orientation; time to harvest was also unaffected. Variation in time to harvest and stem length among cultivars can likely be attributed to innate variations among cultivars and their responses to different environmental conditions including photoperiod. Therefore, cultivar selection would be more important when considering growing fresh-cut sunflowers in high tunnels. Herb fresh weights were not consistent from year to year in any location, suggesting either high tunnel orientation is acceptable for growing them. This study focused on production in small, hobby-size high tunnels. Further research would be necessary to elucidate differences in production parameters with larger tunnels.

\section{Literature cited}

Andersen, C.R. n.d. Chives. 8 Jan. 2019. <https://www.uaex.edu/publications/ pdf/FSA-6082.pdf>.

Blacquière, T., N. Straver, and D. van den Berg. 2002. Possibilities for using photoperiodism to program flowering of sunflowers (Helianthus annuns) in the greenhouse and in the open. Acta Hort. 580:101-109.

Bonarriva, J. 2003. Industry \& trade summary: Cut flowers. U.S. Intl. Trade Commission Publ. 3580.

Carey, E.E., L. Jett, W.J. Lamont, Jr., T.T. Nennich, M.D. Orzolek, and K.A. Williams. 2009. Horticultural crop production in high tunnels in the United States: A snapshot. HortTechnology 19:37-43.

Cavins, T.J., J.M. Dole, and V. Stamback. 2000. Unheated and minimally heated winter greenhouse production of specialty cut flowers. HortTechnology 10:793799.
Dole, J.M. and H.F. Wilkins. 1999. Floriculture - Principles and species. Prentice Hall, Upper Saddle River, NJ.

Ferguson, C.G., P.G. Vuppalapati, M.J. Stone, and E. Gray. 2012. Evaluation of cultivars of sunflowers (Helianthus annuns L.) and selected environments for production of cut flowers. J. Ky. Acad. Sci. 73:90-95.

Fernández-Martinez, J.M., B. PerezVich, and L. Velasco. 2009. Sunflower, p. 155-232. In: J. Vollman and I. Rajcan (eds.). Oil crops, Vol. 4. Springer Sci. Business Media, New York, NY.

Folia, 2015. Garlic chive Allium tuberosum. Plant database/garlic chive plant care. 8 Jan. 2019. <https://myfolia.com/plants/919garlic-chive-allium-tuberosum $>$.

Gardener's Network. 2016. How to grow chives. 7 Feb. 2019. <http://www. gardenersnet.com/herbs/chives.htm>.

Garfinkel, A.R. and K.L. Panter. 2014. Year-round greenhouse production of cut sunflowers in the Rocky Mountain West. HortTechnology 24:743-748.

Gimelli, F., A. Leporati, and L. Maggiora. 2003. The all year round cultivation of cut sunflower in San Remo district. Acta Hort. 614:553-560.

Hayata, Y. and Y. Imaizumi. 2000. Effect of photoperiod on flower bud development of ornamental sunflowers. J. Jpn. Soc. Hort. Sci. 69:708-710.

Jett, L.W. 2004. High tunnel tomato production. Univ. Missouri Ext. Bul. M170. 8 Jan. 2019. <https://mospace. umsystem.edu/xmlui/bitstream / handle $/ 10355 / 51733 / \mathrm{m0170-2004}$. pdf? sequence $=1>$.

Lamont, W.J., Jr. 2009. Overview of the use of high tunnels worldwide. HortTechnology 19:25-29.

Lopez, R.G. and M.A. Ortiz. 2012. Do high tunnels make the cut? 8 Jan. 2019. <http://www.greenhousegrower.com/ article $/ 28959 /$ do-high-tunnels-makethe-cut>.

McMichael, B.L. and J.J. Burke. 1998. Soil temperature and root growth. HortScience 33:947-951.

Morgan, L. 2005. Fresh culinary herb production - A technical guide to the hydroponic and organic production of commercial fresh gourmet herb crops. Suntec (NZ), Tokomaru, New Zealand.

Nau, J. 1999. Ball culture guide. The encyclopedia of seed germination. 3rd ed. Ball Publ., Batavia, IL.

Nau, J. (ed.). 2011. Ball RedBook. Ball Publ., West Chicago, IL. 
Ortiz, M.A., K. Hyrczyk, and R.G. Lopez. 2012. Comparison of high tunnel and field production of specialty cut flowers in the Midwest. HortScience 47:12651269.

Pallez, L.C., J.M. Dole, and B.E. Whipker. 2002. Production and postproduction studies with potted sunflowers. HortTechnology 12:206-210.

Savio, Y. and C. Robinson. 1998. Oregano, winter marjoram, wild marjoram, pot marjoram. In: Specialty and minor crops handbook. 8 Jan. 2019. <https://www. ctahr.hawaii.edu/sustainag/extn_pub/ veggie $\% 20$ pubs/Oregano, $\% 20$ Winter\% 20Marjoram, $\% 20$ Wild $\% 20$ Marjoram, $\%$ 20Pot\%20Marjoram.pdf>.

Schuster, W.H. 1985. Helianthus annuns, p. 98-121. In: A.H. Halevy (ed.). CRC handbook of flowering, Vol. 3. CRC Press, Boca Raton, FL.
Sethi, V.P. 2009. On the selection of shape and orientation of a greenhouse: Thermal modeling and experimental validation. Sol. Energy 83:21-38.

Taber, H.G., B.J. Havlovic, and N.P. Howell. 2009. High tunnel pole bean evaluation. Iowa State Res. Farm Prog. Rpt. 468.

Wells, O.S. and J.B. Loy. 1993. Rowcovers and high tunnels enhance crop production in the northeastern United States. HortTechnology 3:92-95.

Wien, C.H. 2006. Growing black-eyed susan and sunflower out of season. Growing for Market. 15(6):17-18.

Wien, C.H. 2009a. Daylength response of sunflowers. Dept. Hort., Cornell Univ., Ithaca, NY.
Wien, C.H. 2009b. Floral crop production in high tunnels. HortTechnology 19:56-60.

Wien, C.H. 2012a. Cut flower cultural practice studies and variety trials. Dept. Hort., Cornell Univ., Ithaca, NY.

Wien, C.H. 2012b. Sunflower seedling daylength response. Dept. Hort., Cornell Univ., Ithaca, NY.

Yañez, P., H. Ohno, and K. Ohkawa. 2004. Effect of photoperiod on flowering and growth of ornamental sunflower cultivars. Environ. Control Biol. 42:287293.

Yañez, P., H. Ohno, and K. Ohkawa. 2005. Photoperiodic response and vase life of ornamental sunflower cultivars. HortTechnology 15:386-390. 